\title{
The Effect of Employee Engagement, Rewards, and Leadership Style on Turnover Intention at Ijen View Bondowoso Hotel
}

\author{
Pratiwi Yenitasari*, Sampeadi, Wiji Utami \\ Department of Management, Faculty of Economics and Business, University of Jember \\ Jln. Kalimantan 37, Jember 68121 \\ E-mail: pratiwiyenotasari.py@gmail.com
}

\begin{abstract}
The objective of this research is to analyze the effect of employee engagement, rewards, and leadership style on employee turnover intention at Ijen View Bondowoso Hotel. This research is an explanatory research. The sample used in this research consisted of 98 employees. The analysis method used was multple linear regression. The results showed that employee engagement, rewards, and leadership style have a significant and negative effect on turnover intention. These findings imply that the higher employee engagement, rewards, and leadership style, the lower the turnover intention rate.
\end{abstract}

Keywords: Employee Engagement, Leadership Style, Rewards, and Turnover Intention

\section{Introduction}

Following the rapid change of globalization era, the rivalry among companies are getting more competitive that requires every company to have a good strategy to maintain its assets and win the competition. One important asset in an organization or company is human resource. According to Badriyah (2013:15), human resource is a very important asset that its role cannot be replaced by other resources. Human resources need to be managed properly to keep them loyal and having best competence as the basis to create company competitive advantage. A succesful company should have good management in capturing market opportunities and managing human resources according to business needs. Sinambela (2016:340) explains that the bigger the organization, the bigger the number of the employees. This condition will open the possibility of the conflicts or problems, such as turnover intention issue. The turnover intention should be minimized so that it does not disrupt the whole operational system.

One of the best ways to prevent turnover intention is to improve the quality and maintain the high potential employees so that they will feel that the company offers great opportunity to increase their employee capacity. According to Mobley, Horner, and Hollingsworth (1978), the process of turnover intention starts with employee dissatifaction with their job. This dissatisfaction then led to turnover intention to find another job.

The employee will increase their loyalty to the company if they feel that they have a good engagement with the company. According to Wellins and Concerman (2005), employee engagement is an illusory power that motivate the employee to increase their performance to the higher level. This condition will make employee satisfied with their job at the company. According to Harter et al. (2002), employee engagement is an individual involvement and satisfaction along with the feeling of enthusiasm with the job. Moreover, Schaufeli (2002) stated that the employees who are truly engaged with their job will have several characteristics such as being confident of their own abilities and having the

\footnotetext{
* Corresponding author
}

thought that working is fun. Thus, the employees will do their job happily resulting in good and maximum job performance.

Beside rewardss, a leadership style can affect employee intention to leave the organization if they feel uncomfortable with their leader. A leader must choose the right leadership style to direct and manage their employees. The right leadership style is when superiors and subordinates manage to established a good communication. According to Tjiptono (2016:161), leadership style is a leader's method to interact with subordinates. A leader must use the right leadership style to manage their employees because a leader will greatly influence the succes of the company. Human resources management is a challenge to the company especially in hospitality industry to create attractiveness and encouragement for the employee so that they can give good performance while delivering services to the consumers. According to Faldetta et al. (2013), employees working in hospitality industry plays an important role in creating and delivering services to the guests so that they must present their best performance. The hospitality industry has high employee turnover rate (Faldetta et al., 2013). On the other side, a survey results by Compdata in 2016 to 30.000 organizations shows that companies engaged in hospitality industry sector have highest employee turnover rate of $20,7 \%$. If the turnover rate in hotels is high, then the level of turnover intention is also high. A high turnover intention is certainly avoided by a company as it indicates that there are problems in the company.

Bondowoso Regency is one of the tourism destinations in Indonesia. Bondowoso has 13 tourism objects and the number of tourists keeps increasing year by year. According to the data from the Tourism, Youth, and Sports agency of Bondowoso (2018), the number of tourists that visited Bondowoso have significantly increased in the last 5 years. In 2013, it reached 43.223 tourists, in 2014 it reached 57.941 tourists, in 2015 and 2016 the number was increased to 122.683 and 164.649 tourists, and in 2017 it reached 446.840 tourists. The increase of tourists visit urges government to intensively promote the local tourism and develop the supporting infrastructure in tourism, arts, and culture. The large number of tourists visit should be balanced with the 
availability of facilities and infrastructure. According to the Bondowoso Central Bureau of Statistics, in 2017 there were 14 hotels with more rooms available compared to the previous year. This indicates that the hotel industry in Bondowoso is growing fast to fulfill the increasing needs of tourism from year to year.

One of the famous and distinguished hotels in Bondowoso is Ijen View Bondowoso Hotel. This 3-star hotel is located in Kis Mangunsarkoro Street number 188. Considering that there are more new hotels in Bondowoso as the competitors, Ijen View Bondowoso Hotel should deliver best service. The service provided by hotel is often unique and different from each other. However, the turnover rate at Ijen View Bondowoso hotel is quite high. According to the data obtained from the hotel management, the annual employee turnover rate is between 4\%-9\%. The employee turnover data of Ijen View Bondowoso Hotel in 2017 and 2018 is presented in Table 1.

Table 1. Ijen View Bondowoso Hotel Turnover Rate

\begin{tabular}{cccc}
\hline Year & $\begin{array}{c}\text { Number of } \\
\text { Employee }\end{array}$ & \multicolumn{2}{c}{ Outgoing Employee } \\
\cline { 3 - 4 } & 98 & 4 & Percentage(\%) \\
\hline 2017 & 98 & 9 & $4 \%$ \\
2018 & & $4 \%$
\end{tabular}

Source: Ijen View Bondowoso Hotel, 2019.

Table 1 shows that Ijen View Bondowoso Hotel experienced an increase in employee turnover from 2017-218. Based on this phenomenon, this research tried to analyze the effect of employee engagement, rewardss, and leadership style on turnover intention at Ijen View Bondowoso Hotel. The low labour turnover will save the costs needed in the employee selection and recruitment process.

\section{Method}

\section{Research Design}

This research is an explanatory research. According to Sugiyono (2016:11), explanatory research aims to explain the position of researched variables and the relationship between one variable and another. This research aims to obtain information and data about the effect of employee engagement, rewardss, and leadership style on employee turnover intention at Ijen View Bondowoso Hotel.

\section{Population and Sample}

According to Arikunto (2002:108), population is the generalization area that consists of objects and subjects that have certain quality and characteristic as determined by the researchers to be analyze further and then drawing a general conclusion. If the population subject is less than 100, it is better to use all members of the population as the research sample or known as census sampling. The population of this study was all operational employees of Ijen View Bondowoso Hotel that consisted of 98 people.

\section{Data Types and Sources}

The data type used in this study was qualitative data taken from the primary source. The primary data was obtained from the direct interview and questionnaire distribution to get research-related information from the Ijen View Bondowoso Hotel employees.

\section{Data Analysis dan Method}

Data analysis method used in this study is multiple linear regression analysis. The multiple linear regression is used to determine the effect of two or more independent variables on the dependent variable. In this study, the regression analysis was used to determine the effect of employee engagement, rewardss, and leadership style on employee turnover intention at Ijen View Bondowoso Hotel.

\section{Results and Discussions}

\section{Results}

Characteristic of Respondents

a) Respondents characteristic by Age

Table 2. Number of Respondents by Age

\begin{tabular}{ccc}
\hline Age & Total & Percentage $(\%)$ \\
\hline 20-30 years & 32 & 32,7 \\
$31-40$ years & 15 & 15,3 \\
$41-50$ years & 39 & 39,8 \\
$>50$ years & 12 & 12,2 \\
Total & 98 & 100 \\
\hline
\end{tabular}

Table 2 shows the total sample of 98 respondents that mostly consists of the employees of productive age (under 51 years old), which is 86 persons of $87,8 \%$. As we know that working in a hotel make the employees have to serve the hotel guests with different characters, needs, and wants that can potentially lead to several problems that can cause stress at work. Most of the employees at Ijen View Bondowoso Hotel have mature age so it is assumed that they can manage the stresses and emotion at work. At that mature age, it is also assumed that the employee are also unwilling to change the workplaces of finding a new job as they would like to have a stabil and permanent job.

b) Respondents Characteristic by Gender

Table 3. Number of Respondent by Gender

\begin{tabular}{ccc}
\hline Gender & Total & Percentage (\%) \\
\hline Male & 82 & 83,7 \\
Female & 16 & 16,3 \\
\hline Total & 98 & 100 \\
\hline
\end{tabular}

Table 3 shows that of 98 respondents, 82 respondents or $83,7 \%$ were men, while the other 16 respondents or $16,3 \%$ were women. These results show that in the hospitality industry, especially hotel, most workers are male. Unlike normal office hours from 8 am or 9 am to 4 pm or $5 \mathrm{pm}$, hotel has longer working schedule up to 24 hours and the employee is working by shifts that can be changed at anytime. It requires employees to have good stamina. Therefore, it is common to see more male employee working in the hotels. In terms of gender, it was also found that women are more likely to do the work turnover than men. There are several factors that influence the work turnover and one of them is because women can have two big roles and responsibilities, especially to those who have been married, they both act as housewives and career women. 
c) Respondents Characteristic by Length of Work

Table 4. Number of Respondents by Length of Work

\begin{tabular}{ccc}
\hline Length of Work & Total & Percentage $(\%)$ \\
\hline 0-5 years & 20 & 20,4 \\
5-10 years & 37 & 37,8 \\
$>10$ years & 41 & 41,8 \\
\hline Total & 98 & 100 \\
\hline
\end{tabular}

Table 4 shows that the majority of respondent in this study worked more than 10 years $(41,8 \%)$. Previous studies show negative correlation between length of work and turnover, which means that the longer the length of work, the lower the turnover rate. In addition, the length of employee works is related to better skills, speed, and coordination at work so that the job can be performed optimally.

\section{Validity Test}

Validity test is performed to asses the extend of data validity obtained from the questionnaire distributed to respondents. Validity test refers to Pearson Product Moment. The results of validity test can be seen in Table 5. According to Table 5, all indicators of employee engagement $\left(\mathrm{X}_{1}\right)$, rewards $\left(\mathrm{X}_{2}\right)$, leadership style $\left(\mathrm{X}_{3}\right)$, and turnover intention $(\mathrm{Y})$ have the value of $r$ statistics $>r$ table (0.198). This means that all indicators of the variables are valid or it can be said that all items can be used as valid tools to collect research data.

\section{Reliability Test}

This reliability test is used to measure the feasibility of the indicators used in the research questionnaire. A variable is reliable if the Cronbach's Alpha value is bigger than 0.60. Table 5 presents the results of reliability test. Table 5 shows that $\alpha$ value of each variable is bigger than reliability critical value. The $\alpha$ value of employee engagement variable $\left(\mathrm{X}_{1}\right)$ is $0.753>0.60$, the $\alpha$ value of rewards variable $\left(\mathrm{X}_{2}\right)$ is $0.732>$ 0.60 , the $\alpha$ value of leadership style $\left(\mathrm{X}_{3}\right)$ is $0.675>0.60$, and the $\alpha$ value of turnover intention (Y) is $0.773>0.60$. Therefore, it can be concluded that all statement items in the questionnaire can be trusted since the measurement results are relatively consistent, even though the question is given twice or more to different respondents. Thus, the questionnaire can be used for further research that use the same variables.

Table 5. Results of Validity Test

\begin{tabular}{lcccc}
\hline \multicolumn{1}{c}{ Variable } & Item & r Statistics & r Table & Results \\
\hline Employee & $\mathrm{X}_{1} .1$ & 0.596 & 0.198 & Valid \\
Engagemen & $\mathrm{X}_{1} .2$ & 0.575 & 0.198 & Valid \\
$\mathrm{t}\left(\mathrm{X}_{1}\right)$ & $\mathrm{X}_{1} .3$ & 0.726 & 0.198 & Valid \\
& $\mathrm{X}_{1} .4$ & 0.475 & 0.198 & Valid \\
& $\mathrm{X}_{1} .5$ & 0.559 & 0.198 & Valid \\
& $\mathrm{X}_{1} .6$ & 0.519 & 0.198 & Valid \\
& $\mathrm{X}_{1} .7$ & 0.415 & 0.198 & Valid \\
& $\mathrm{X}_{1} .8$ & 0.618 & 0.198 & Valid \\
& $\mathrm{X}_{1} .9$ & 0.743 & 0.198 & Valid \\
\cline { 2 - 5 } Rewardss & $\mathrm{X}_{2} .1$ & 0.591 & 0.198 & Valid \\
$\left(\mathrm{X}_{2}\right)$ & $\mathrm{X}_{2} .2$ & 0.685 & 0.198 & Valid \\
& $\mathrm{X}_{2} .3$ & 0.683 & 0.198 & Valid
\end{tabular}

\begin{tabular}{lcccc} 
& $\mathrm{X}_{2} .4$ & 0.612 & 0.198 & Valid \\
& $\mathrm{X}_{2.5} .5$ & 0.745 & 0.198 & Valid \\
Leadership & $\mathrm{X}_{2} .6$ & 0.624 & 0.198 & Valid \\
\cline { 2 - 5 } Style $\left(\mathrm{X}_{3}\right)$ & $\mathrm{X}_{3} .1$ & 0.658 & 0.198 & Valid \\
& $\mathrm{X}_{3} .2$ & 0.633 & 0.198 & Valid \\
& $\mathrm{X}_{3} .3$ & 0.555 & 0.198 & Valid \\
& $\mathrm{X}_{3} .4$ & 0.593 & 0.198 & Valid \\
& $\mathrm{X}_{3} .5$ & 0.593 & 0.198 & Valid \\
Turnover & $\mathrm{X}_{3} .6$ & 0.678 & 0.198 & Valid \\
\cline { 2 - 5 } Intention & $\mathrm{Y} 1$ & 0.646 & 0.198 & Valid \\
(Y) & $\mathrm{Y} 2$ & 0.605 & 0.198 & Valid \\
& $\mathrm{Y} 3$ & 0.582 & 0.198 & Valid \\
& $\mathrm{Y} 4$ & 0.548 & 0.198 & Valid \\
& $\mathrm{Y} 5$ & 0.705 & 0.198 & Valid \\
& $\mathrm{Y} 6$ & 0.704 & 0.198 & Valid \\
& $\mathrm{Y} 7$ & 0.748 & 0.198 & Valid \\
\hline
\end{tabular}

Table 6. Results of Reliability Test

\begin{tabular}{lccl}
\hline \multicolumn{1}{c}{ Variables } & $\alpha$ Value & $\alpha$ Statute & Results \\
\hline $\begin{array}{l}\text { Employee Engagement } \\
\left(\mathrm{X}_{1}\right)\end{array}$ & 0.753 & 0.60 & Reliable \\
Rewards $\left(\mathrm{X}_{2}\right)$ & 0.732 & 0.60 & Reliable \\
Leadership Style $\left(\mathrm{X}_{3}\right)$ & 0.675 & 0.60 & Reliable \\
Turnover Intention $(\mathrm{Y})$ & 0.773 & 0.60 & Reliable \\
\hline
\end{tabular}

Table 7. Results of Normality Test

\begin{tabular}{cc}
\hline Variables & Kolmogrov Smirnov Values \\
\hline Employee Engagement & 0,133 \\
$\left(\mathrm{X}_{1}\right)$ & 0,057 \\
Rewards $\left(\mathrm{X}_{2}\right)$ & 0,101 \\
Leadership Style $\left(\mathrm{X}_{3}\right)$ & 0,080 \\
Turnover Intention $(\mathrm{Y})$ & \\
\hline
\end{tabular}

\section{Data Normality Test}

The normality test is used to test whether the collected data are normally distributed or not. The data normality test can be performed using Kolmogrov Smirnov by setting the significance level $(\alpha)$ of $5 \%$. If the significance value is more than 0.05 , then the data are normally distributed. Table 7 presents the results of data normality test.

Based on Table 7, each of research variable has Kolmogrov Smirnov value of the followings, employee engagement $\left(\mathrm{X}_{1}\right)$ 0.133 , rewards $\left(\mathrm{X}_{2}\right) 0.057$, leadership style $\left(\mathrm{X}_{3}\right) 0.101$, and turnover intention $(\mathrm{Y})$ 0.080. All variables have significance values bigger than 0.05 which means that the data are normally distributed.

\section{Multiple Linear Regression Analysis}

The multiple regression analysis is performed to determine the effect of independent variables (Y) on dependent variable $(\mathrm{X})$. The independent variables of this study were employee engagement $\left(X_{1}\right)$, rewards $\left(X_{2}\right)$, and eadership style $\left(X_{3}\right)$, while the dependent variable was turnover intention (Y). The following Table 8 presents the results of multiple linear regression. 
Table 8. Results of Multiple Linear Regression Analysis Coefficientsa

\begin{tabular}{cccc} 
Model & $\mathrm{B}$ & $\mathrm{t}$ & $\mathrm{Sig}$ \\
\hline (Constant) & 8.135 & 3.107 & .002 \\
\hline $\mathrm{X} 1$ & -.165 & -2.228 & .028 \\
$\mathrm{X} 2$ & -.279 & -2.222 & .029 \\
$\mathrm{X} 3$ & -.304 & -2.179 & .032
\end{tabular}

Based on Table 8 , the multiple linear regression equation is as follows:

$\mathrm{Y}=8,135-0,165 \mathrm{X}_{1}-0,279 \mathrm{X}_{2}-0,304 \mathrm{X}_{3}+\mathrm{e}$

a. A constant value of 8.135 shows the turnover intention variable value $(\mathrm{Y})$ when employee engagement $\left(\mathrm{X}_{1}\right)$, rewards $\left(\mathrm{X}_{2}\right)$, and leadership style $\left(\mathrm{X}_{3}\right)$ is zero.

b. $b_{1}=-0,165$ is the contribute of employee engagement $\left(X_{1}\right)$ that effects on turnover intention (Y). The regression coefficient $\left(b_{1}\right)$ of $-0,165$ shows the negative effect of employee engagement $\left(\mathrm{X}_{1}\right)$ on turnover intention $(\mathrm{Y})$ with the assumption that $X_{2}$ and $X_{3}$ variables are constan.

c. $b_{2}=-0.279$ is the contribution of rewards $\left(X_{2}\right)$ that affects turnover intention $(\mathrm{Y})$. The regression coefficient $\left(\mathrm{b}_{2}\right)$ of -0.279 shows the negative effect of rewards $\left(\mathrm{X}_{2}\right)$ on turnover intention (Y) with the assumption that $\mathrm{X}_{1}$ and $\mathrm{X}_{3}$ variables are constant. This means that the higher rewards $\left(\mathrm{X}_{2}\right)$, the lower turnover intention rate $(\mathrm{Y})$, and viceversa.

d. $b_{3}=-0.304$ is the contribution of leadership style $\left(X_{3}\right)$ that affects turnover intention $(\mathrm{Y})$. The regression coefficient $\left(\mathrm{b}_{3}\right)$ of -0.304 shows the negative effect of leadership style $\left(\mathrm{X}_{2}\right)$ on turnover intention $(\mathrm{Y})$ with the assumption that $\mathrm{X}_{1}$ and $\mathrm{X}_{2}$ variables are constant. This means that the better leadership style $\left(\mathrm{X}_{3}\right)$ the lower the turnover intention (Y), and viceversa.

\section{Classical Assumption Test}

\section{a. Multicollinearity Test}

The multicollinearity test is a test of classical assumption test to prove the independent variables in a model do not corelate with each other. We can detect the multicollinearity by analyzing the tolerance value and VIF on both regression equation models. Table 9 presents the results of multicollinearity test.

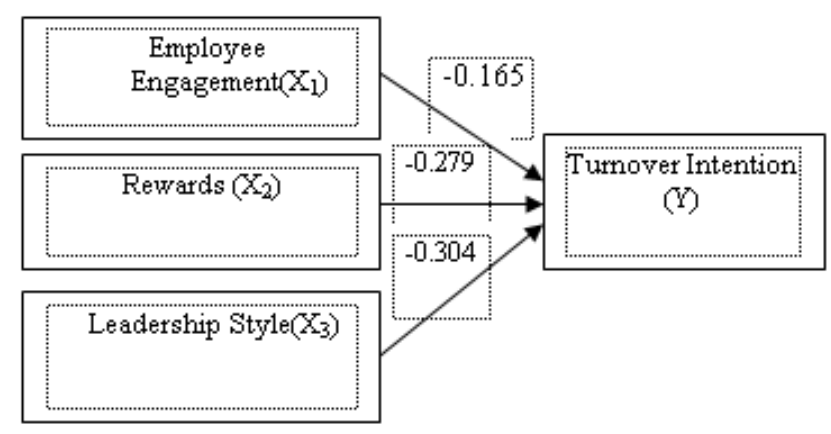

Table 9. Results of Multicollinearity Test

\begin{tabular}{ccc}
\hline Variable & VIF & Results \\
\hline Employee Engagement & 1.236 & VIF $<10$ \\
$\left(\mathrm{X}_{1}\right)$ & 2.124 & \\
Rewards $\left(\mathrm{X}_{2}\right)$ & 2.287 & \\
Leadership style $\left(\mathrm{X}_{3}\right)$ & \\
\hline
\end{tabular}

Based on table 9, it is known that multicollinearity did not occur in the model since each of the VIF value was less than 10 or VIF $<10$. Thus, it can be concluded that all of the variables consisted of employee engagement $\left(\mathrm{X}_{1}\right)$, rewards $\left(\mathrm{X}_{2}\right)$, and leadership style $\left(\mathrm{X}_{3}\right)$ have no multicollinearity.

\section{Heteroscedasticity Test}

Heteroscedasticity is a condition where there are variant inequality of the residuals from one observation to another. The heteroscedasticity test aims to determine the deviations from the classical assumption conditions in linear regression. Agood regression model must be free from heteroscedasticity. The heteroscedasticity test used is the Glejser test, i.e., if the significance value of the independent variable with absolute residuals is more than 0.05 , then there is no heteroscedasticity problem. Table 10 presents the results of heteroscedasticity test.

Table 10. Results of Heteroscedasticity Test

\begin{tabular}{ccc}
\hline Variables & Sig. & Results \\
\hline Employee Engagement & .352 & No \\
$\left(\mathrm{X}_{1}\right)$ & .635 & \\
Rewards $\left(\mathrm{X}_{2}\right)$ & .057 & \\
Leadership style $\left(\mathrm{X}_{3}\right)$ & \\
\hline
\end{tabular}

Based on Table 10, it is known that the model is free from heteroscedasticity. This can be seen from the heteroscedasticity results where the significance value of each variable is bigger than 0.05 . Then, according to the decision making in a glacier test, it can be concluded that there is no heteroscedasticity in the regression model.

\section{Hypothesis Test}

a) Partial Test (t Test)

The $\mathrm{t}$ test aims to determine the partial effect of each independent variables on dependent variable. The hypothesis test is performed using the $t$ test by comparing the values of $t$ statistics and $t$ table. If the value of $t$ statistics $>t$ table, then $\mathrm{H}_{\mathrm{a}}$ is accepted $\left(\mathrm{H}_{0}\right.$ rejected $)$. The results of $\mathrm{t}$ test are presented in Table 10.

Table 10. Results of t Test

\begin{tabular}{cccc}
\hline Variables & $\mathrm{t}$ statistics & $\mathrm{t}$ table & Sig. Value \\
\hline $\mathrm{X}_{1}$ & -2.228 & 1.984 & .028 \\
$\mathrm{X}_{2}$ & -2.222 & 1.984 & .029 \\
$\mathrm{X}_{3}$ & -2.179 & 1.984 & .032 \\
\hline
\end{tabular}

According to Table 10, we can conclude the followings:

a. The employee engagement variable $\left(\mathrm{X}_{1}\right)$ has the $t$ statistics value of -2.228 and the $t$ table value of 1.984 with the significance value of 0.028 . The value of $t$ statistices $>t$ table, then the $\mathrm{H}_{1}$ is accepted, which means that the employee engagement variable has a significant effect on turnover intention.

b. The rewards variable $\left(\mathrm{X}_{2}\right)$ has the $\mathrm{t}$ statistics value of -2.222 and $t$ table value of 1,984 with the significance value of 0.029 or,the $t$ count value $>\mathrm{t}$ table value. Then, $\mathrm{H}_{2}$ is 
accepted, which means thata the rewards variable has a significant effect on turnover intention partially.

c. The leadership style variable $\left(\mathrm{X}_{3}\right)$ has the $\mathrm{t}$ statistics value of -2179 and t table value of 1.984 with the significance value of 0.032 . This implies that the $t$ count value $>t$ table value, then $\mathrm{H}_{3}$ is accepted, which means that the leadership style has a significant effect on turnover intention.

\section{Discussions}

\section{The Effect of Employee Engagement on Employee Turnover Intention at Ijen View Hotel Bondowoso.}

The results of multiple linear regression analysis showed that the regression coefficient value of employee engagement is $-0,165$. The correlation showed by the regression coefficient was negative which means that the higher employee engagement, the lower turnover intention. The results of hypothesis test ( $t$ test) show that employee engagement has a negative significant effect on employee turnover intention at Ijen View Hotel Bondowoso.

The employee engagement has great effect in lowering the turnover intention level. According to Handoko (2008:117), the higher engagement level, the lower the number of employees resign from the company. The employees who have high employee engagement will give positive impact to their careers so that the employee will survive better in the company. From the research results, it can be stated that the employees at Ijen View Hotel Bondowoso have a good employee engagement. It can be seen from the majority of the answersin the questionnaire that most answered agreed and strongly agreed on the indicators of mental toughness, giving the best effort, feeling enthusiastic, and feeling proud towards the company. The mental toughness indicator has the highest effect on turnover intention at employee engagement variable. It indicates that the employees have performed a good job at Ijen View Hotel Bondowoso. The interview results also showed the employees are very happy when they do their jobs because they assume that their work are in line with their skills. This leads to the condition that the employees have no intention to quit and look for another job. The Ijen View Hotel Bondowoso realized that the bad or low employee engagement will give bad impact to the work results. However, it is also found that some employees are less active in performing their job resulting low level of performance at work. The results of this research are in line with the previous studies by Nugroho (2017) and Rachman and Dewanto (2016) proving that employee engagement significantsly affects turnover intention.

\section{The Effect of Rewards on Employee Turnover Intention At Ijen View Hotel Bondowoso.}

The result of multiple linear regression analysis showed that the coefficient value of rewards variable is -0.279 . The correlation that showed by regression coefficient is negative, which means that the higher the rewards, the lower turnover intention. The hypothesis test results show that rewards has a negative significant effect on employee turnover intention at Ijen View Hotel Bondowoso. The results of respondent answers in the research questionnaire showed that the rewards variable measured by 6 items of is perceived positively by the employees. Therefore, it can be concluded that, in general, Ijen View Hotel Bondowoso has a good rewards system. According to the answer rating criteria, the rewards variable obtained a good rating with a percentage of $63,5 \%$, while the turnover intention variable obtained a very good rating with a percentage of $78,8 \%$.

The rewards are one of the employees motivation to upgrade their productivity and then reduce turnover intention. But, not all companies have a good and fair rewards system. According to Hasibuan (2010), the rewards is given for the services provided by the employee in a company. The rewards is not simply about rights and obligations, but most importantly, it is about creating enthusiasm to be passionate about working. At Ijen View Hotel Bondowoso, the employees have a good understanding about rewards. It can be seen from the majority answers that most employees agreed and strongly agreed about the indicators of salary, incentives, examinations, leave, and benefits provided by the company. Moreover, the rewards given to the employees are fair and objective in accordance with the employee performance.

At Ijen View Hotel Bondowoso, the rewards given are not only in forms of financial rewards, but also non-financial rewards such as recognition and compliments from superiors and fellow colleagues. These efforts were made by Ijen View Hotel management in order to motivate their employees to perform better and having enthusiasm to always increase their work quality so that they can give best services to the guess. The employees of Ijen View Hotel Bondowoso also evaluated that the financial rewards in forms of salaries, incentives, and other benefits are given proportionally. However, the interview results showed the employees hope that it would be better if the management of Ijen View Hotel provides more leave to the employees. The compliments are given to the employees when their are able to complete the work. The employees of Ijen View Hotel Bondowoso often get overtime work until midnight, but it will be compensated financially by giving extra bonus. It is hoped that the financial and non-financial rewards will motivate employees to have better work performance. The findings of this research support previous study by Rohmanaji, Warso, and Paramita (2016) proveing that that rewards have a significant effect on turnover intention.

\section{The Effect of Leadership Style on Employee Turnover Intention At Ijen View Hotel Bondowoso.}

The indicators of leadership style in this study are work tools, clear instructions, critics giving, subordinates coordination, coordinates supervision, and the implementation of work procedures. The results of multiple linear regression analysis showed that the coefficient value of leadership style variable is -0.304 . The correlation showed by the regression coefficient is negative which means the better the leadership style, the lower the turnover intention rate.

The results of respondent answers showed that the leadership style variable as measured by 6 items is perceived positively. Thus, it can be concluded that, in general, Ijen View Hotel Bondowoso management has good leadership style. According to the answer rating criteria, the leadership style variable obtained a good rating with a percentage of $63,6 \%$ while the turnover intention variable obtained a very good rating with a percentage of $78,8 \%$. 
According to Hasibuan (2011:162), a leader must influence subordinates behavior so they can work productively to achieve company goals. In order to achieve the company goals, the employees should do the work in accordance with their rights obligations and following the order from their leader. As stated earlier, Ijen View Hotel Bondowoso has a good leadership style. The hotel leaders are always giving right directions to the employees so that they can work properly The leaders are also deliver fair and objective critics and warning to the employees performing some mistakes at work. However, from the results of interviews, some employees shared that some leaders are not always giving fully supervision at work. Eventhough, there is no routine inspection, the majority of of the employees at Ijen View Hotel Bondowoso are committed to work and performing their best efforts. The results of the study are in line with the results of previous study by Saklit (2017) proving that leadership style has a significant effect on turnover intention.

\section{Conclusion}

Based on the results and discussion, this research draw the following conclusions:

a. The employee engagement has a negative and significant effect on employee turnover intention at Ijen View Bondowoso Hotel which means that the higher the level of employee engagement, the lower the level of turnover intention. The results showed that Ijen View Hotel Bondowoso has a good employee engagement as described in positive perception about the their work.

b. The rewards has a negative and significant effect on employee turnover intention of Ijen View Hotel Bondowosos. The results showed that the hotel has a good rewards system that affect the turnover intention rate. Most employees agreed that the rewards system is fair and proportional.

c. The leadership style has a negative and significant effect on turnover intention. The results showed that the hotel management has a good leadership style that most employees feel convenience to work with the leaders.

\section{Suggestion}

This research proposes several suggestions as the followings:

a. For the management of Ijen View Hotel, related to employee engagement, the management should give more attention especially to the less active employees since it will potentially impact on the process of achieving company goals. Related to the rewards, the Ijen View Hotel can upgrade the rewards program such as giving more leave and compliments to the employees to maintain their long-term relationship with the company. Related to the leadership style, the leaders should have more positive interaction with their employees. The leaders must also motivate and encourage their subordinates to perform better.

b. Future studies can explore other variables affecting the level of turnover intention in a company or organization. Future research may also explore other companies, not only in hospitality industry, but also in other sectors as each company has different organizational culture, rewards system, and leadership style.

\section{References}

Arikunto, S. (2002). Metodologi Penelitian Suatu Pendekatan Proposal. Jakarta: PT. Rineka Cipta.

Badriyah, M. (2013). Manajemen Sumber Daya Manusia. Cetakan I. Bandung: CV Pustaka Setia.

Faldetta, G., Fasone, V., \& Provenzano, C. (2013). Turnover in the hospitality industry: can reciprocity solve the problem? PASOS Revista de Turismo y Patrimonio Cultural, 11(4), 583-595. https://doi.org/10.25145/j.pasos.2013.11.052

Handoko, T. H. (2008). anajemen Personalia dan Sumber Daya Manusia. Yogyakarta: BPFE Pres.

Harter, J. K., Schmidt, F. L., \& Hayes, T. L. (2002). Business-unit-level relationship between employee satisfaction, employee engagement, and business outcomes: A meta-analysis. Journal of Applied Psychology, 87(2), 268-279. https://doi.org/10.1037/00219010.87.2.268

Hasibuan, M. S. P. (2016). Manajemen Sumber Daya Manusia (Revition). Jakarta: PT Bumi Aksara.

Mobley, W. H., Horner, S. O., \& Hollingsworth, A. T. (1978). An Evaluation of Precursors of Hospital Employee Turnover. Journal of Applied Psychology, 63(4), 408-414. https://doi.org/10.1037/00219010.63.4.408

Nugroho, A. (2017). Nugroho, A. 2017. Pengaruh Employee Engagement Terhadap Turnover Intentions Dan Kepuasan Kerja Sebagai Variabel Intervening (Studi Pada Karyawan Hypermart Department Store Di Mall Lippo Plaza Jogja). In Universitas Muhammadiyah Yogyakarta.

Rachman, L., \& Dewanto, A. (2016). Pengaruh Employee Engagement terhadap Kepuasan Kerja dan Turnover Intention Perawat (Studi pada Rumah Sakit Wava Husada Kepanjen Malang). Jurnal Aplikasi Manajemen, 14(2), 322-333. https://doi.org/10.18202/jam23026332.14.2.14

Rohmanaji, D., Warso, M. M., \& Paramita, P. D. (2016). Pengaruh Reward, Salary Dan Job Satisfaction Terhadap Turnover Intention Karyawan Di Sarinah Shop And Tailor. 2(2).

Saklit, I. W. (2017). Pengaruh Gaya Kepemimpinan Dan Pengembangan Karir Terhadap Intensi Turnover: Kepuasan Kerja Sebagai Mediator. Jurnal Manajemen, 21(3), 472-490. https://doi.org/10.24912/jm.v21i3.263

Schaufeli, wilmar b., Salanova, M., \& Bakker, vicente gonz 'alez-rom 'a arnold b. (2002). The Measurement of Engagement and Burnout: a Two Sample Confirmatory Factor Analytic Approach. Journal OfHappiness Studies, 3, 71-92.

Sinambela, L. P. (2016). Manajemen Sumber Daya Manusia. Jakarta: PT Bumi Aksara.

Sugiyono. (2016). Metode Penelitian Administrasi. Bandung: Alfabeta.

Tjiptono, F. (2014). Pemasaran Jasa: Prinsip, Penerapan dan Penelitian. Andi Offset, Yogyakarta.

Wellins, R. S., \& Concelman, J. (2005). Creating a Culture for Engagement,Workforce Performance Solutions. Retrieved from www.WPSmag.com, on 30th August 2010. 